\title{
Congenital cutaneous fibropapillomatosis in a warmblood foal
}

\author{
Congenitale cutane fibropapillomatose bij een warmbloedveulen
}

\author{
${ }^{1}$ E. Van de Water, ${ }^{2}$ R. de Moree, ${ }^{3}$ H. de Cock, ${ }^{4}$ T. Picavet, ${ }^{1}$ A. Martens, ${ }^{1}$ M. Oosterlinck \\ ${ }^{1}$ Department of Surgery and Anesthesiology, Faculty of Veterinary Medicine, Ghent University, \\ Salisburylaan 133, 9820 Merelbeke, Belgium \\ ${ }^{2}$ Breeërsteenweg 240, 3640 Kinrooi, Belgium \\ ${ }^{3}$ Veterinary Pathology Services/AML, Emiel Vloorsstraat 9, 2020 Antwerpen, Belgium \\ ${ }^{4}$ DBP Veterinary Services, Spelonckvaart 44, 9180 Moerbeke-Waas, Belgium
}

Eline.VandeWater@UGent.be

\begin{abstract}
$\Lambda_{\text {batract }}$
In this report, clinical and histological findings of a rare case of a large congenital fibropapilloma on the forehead of a warmblood foal are reported. Surgical excision was curative and no recurrence was observed after nine months. The foal did not present any other abnormalities. Morphologically, the lesion was classified as a fibro-epithelial type of skin hamartoma. The fibrous component has thus far only been reported in pigs. Although fibropapillomas are common in adult animals and are associated with papillomavirus infection, this association has not been demonstrated in foals and piglets. Additionally, there were no histopathological indications of papillomavirus infection in the present study, nor could PCR reveal the presence of papillomavirus DNA.
\end{abstract}

\section{SAMENVATTING}

In deze casuïstiek wordt een zeldzaam geval van een congenitaal fibropapilloma op het voorhoofd van een warmbloedveulen beschreven. Chirurgische excisie van de massa was succesvol en na negen maanden nog steeds zonder recidief. Er werden geen andere abnormaliteiten bij het veulen vastgesteld. Morfologisch gezien betreft het letsel een fibro-epitheliaal type hamartoma van de huid. De fibreuze component werd tot dusver enkel bij varkens beschreven. Alhoewel bij volwassen dieren fibropapilloma's vaak voorkomen en geassocieerd zijn met papillomavirusinfecties, werd zowel bij veulens als biggen voor de congenitale fibropapilloma's nog geen virale oorzaak aangetoond. Ook in deze casus waren geen histopathologische indicaties voor infectie met papillomavirus en kon evenmin de aanwezigheid van papillomavirus-DNA aangetoond worden met PCR.

\section{INTRODUCTION}

Congenital cutaneous (fibro)papillomas have occasionally been described in cattle (Desrochers et al., 1994) and pigs (Vitovec et al., 1999; Misdorp, 2003a; Nishiyama et al., 2011), and have only rarely been reported in horses (Garma-Aviña et al., 1981; White et al., 2004; Ruppin et al., 2013). Most of these cases are single verrucous or cauliflower-like lesions that occur on the head (Garma-Aviña et al., 1981; Misdorp, 2003b; White et al., 2004). However, recently, extensive congenital lesions with a linear distribution have been described (Ruppin et al., 2013). In this report, the clinical and histological findings and the treatment of a large congenital fibropapilloma on the forehead of a warmblood foal is described.

\section{CASE REPORT}

After normal gestation, a pluriparous, seventeenyear-old, grey warmblood mare gave birth to a male foal with a pedunculated, black, oval, exophytic mass of approximately $10 \times 9 \times 3 \mathrm{~cm}$ on his forehead (Figure 1). The mass had a rubbery consistency and was not painful on palpation. Parturition went uneventfully. The mare had been routinely vaccinated against tetanus and influenza but not against EHV-1 and -4. The owner's herd did not have a history of papillomavirus infection and did not have any contact with cattle.

No other abnormalities were noticed in the foal. At around seven hours of age, the mass was excised en bloc after local infiltration of anesthetic solution (Pro- 
caine hydrochloride 4\%; VMD, Arendonk, Belgium) at the basis of the peduncle (Figure 2). A central artery was ligated and the small wound ( $2 \mathrm{~cm}$ diameter) was closed with a simple continuous subcutaneous suture of polyglactin 910 (Vicryl USP 2/0; Ethicon, Johnson \& Johnson, Norderstedt, Germany) and skin staples (Manipler AZ-35W, B Braun, Melsungen, Germany). Wound healing was uneventful (Figure 3) and there was no recurrence nine months later. Histology revealed a cauliflower-like, exophytic proliferation of the skin, lined by a highly irregular hyperplastic, pigmented parakeratotic epithelium. The epithelium rested on a broad branched peduncle of highly vascularized collagen stroma. The lesion was diagnosed as fibro-epithelial hamartoma, compatible with equine congenital cutaneous fibropapillomatosis (Figure 4). There was no histological evidence (inclusion bodies, koilocytes, clumping of keratohyalin granules) of papillomavirus infection. Identification of viral particles was attempted by screening of the tissue with an available consensus-PCR for human papillomaviral DNA (MY9/11), RT-PCR for BPV-1 \& 2 DNA (Bogaert et al., 2007), and conventional PCR for EcPV-1 (Postey et al., 2007), EcPV-2 (Scase et al., 2010) and EcPV-3 DNA (van den Top et al., 2015), but all results were negative.

\section{DISCUSSION}

In this case report, the clinical and histological findings and treatment of a rare case of a large congenital fibropapilloma on the forehead of a warmblood foal is detailed. Notwithstanding the fact that the macroscopic aspect of these lesions was rather pathognomonic, the low prevalence may make the diagnosis challenging for equine practitioners. Nevertheless, surgical excision is curative and can easily be performed in the field.

It has been stated that congenital papillomas show the same clinical and histological features as epidermal hamartomas (nevi) in humans (Scott and Miller, 2003; White et al., 2004; Scott and Miller, 2011; Rup-

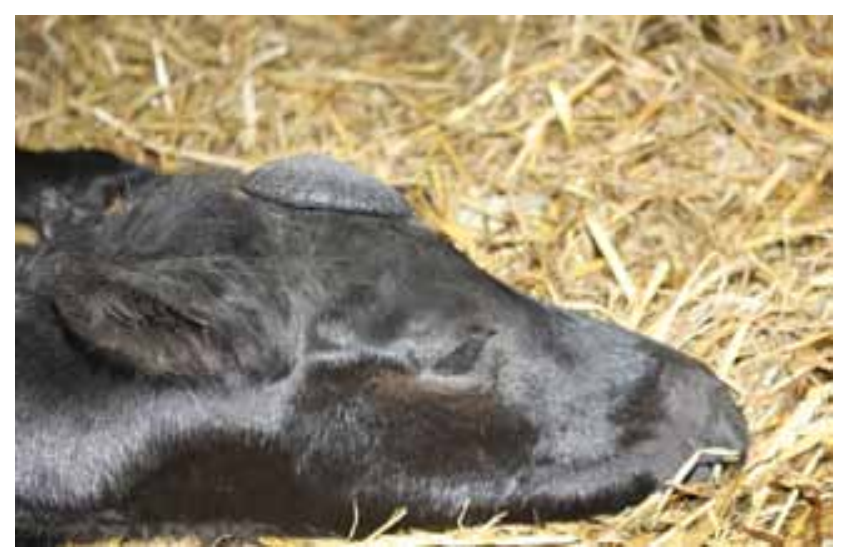

Figure 1. Macroscopic lateral view of the black, flat, oval, pedunculated exophytic mass with a rubber aspect of approximately $10 \times 9 \times 3 \mathrm{~cm}$ on the foal's forehead.

pin et al., 2013). The latter are benign tumor-like lesions consisting of hyperplasia of normal mature tissue components, due to an embryonic developmental error (Stosiek et al., 1994; Campen et al., 2003). Based on these histological similarities between equine congenital papillomas and human nevi, some controversy in terminology has been introduced in the veterinary literature. However, the combination of epithelium and fibrous tissue as seen in the present case, has not been described in human nevi. Therefore, the authors prefer the term congenital fibropapilloma in this case, which previously has only been described in piglets (Vitovec et al., 1999; Nishiyama et al., 2011).

Besides the embryonic developmental error as seen in human nevi, the macroscopic appearance is highly similar to that seen in viral papillomas, and it could be speculated that the congenital appearance of these lesions in horses is explained by intrauterine infection with papillomavirus. In piglets born with similar congenital fibropapillomatosis lesions, an association has been made with the presence of cutaneous viral papillomas on prepuce and scrotum of boars. However, in the case of the piglets, no viral particles were identified ultrastructurally (Vitovec et al., 1999).

A viral component in this disease would open perspectives for medical treatment and/or vaccination in

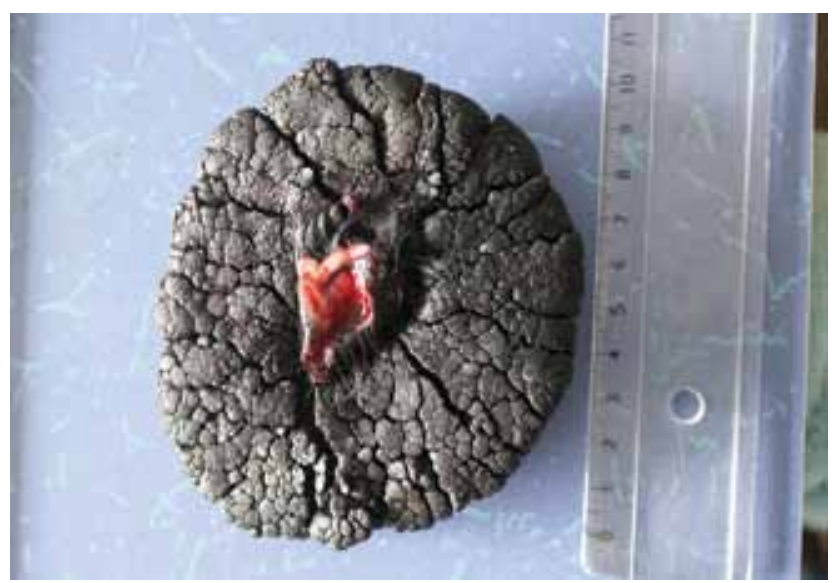

Figure 2. A. Macroscopic dorsal and B. ventral view of the mass after surgical excision through the vascularized peduncle. 
case excision would be difficult or even impossible, for example in the ocular region. In contrast with equine cutaneous papillomas acquired later in life, and in contrast with congenital anogenital papillomas associated with papillomavirus infection in humans (Dias et al., 1995), this case study is in agreement with other reports that histopathological evidence of viral infection in equine congenital papillomas is lacking. Therefore, clinical or experimental proof for this viral pathogenesis remains elusive. Immunohistochemical examination of equine papillomas can be performed as described in a case series by White et al. (2004), but this test does not use specific equine antibodies. Furthermore, PCR can be used to detect viral DNA (Postey et al., 2007), and recent studies have shown the presence of EcPV-1 in equine cutaneous papillomas, EcPV-2 in genital papillomas and EcPV-3 in aural plaques (Ghim et al., 2004; Scase et al., 2010; Lange et al., 2011). However, depending on the developmental stage of the papilloma, Postey et al. (2007) suggested that papillomavirus DNA may be present at levels less than detectable by PCR, and the same limitation may apply to the immunohistochemical detection of viral antigen (Junge et al., 1984). Based on these studies, specificity of immunohistochemical and PCR analysis may be suboptimal and negative results may not rule out viral infection. Moreover, even the lack of histological abnormalities does not rule out a viral etiology, as bovine papillomavirus DNA has been detected in histologically normal equine skin (Bogaert et al. 2008).

It is unclear whether spontaneous regression would be possible in large lesions as described in the present study. Retrospective analysis of a larger sample of histologically confirmed cases and follow-up of cases without surgical treatment are needed to elucidate this issue. Based on the low prevalence, multicenter studies will therefore be required. Moreover, additional molecular studies are required to investigate whether or not papillomavirus is involved in this pathology.

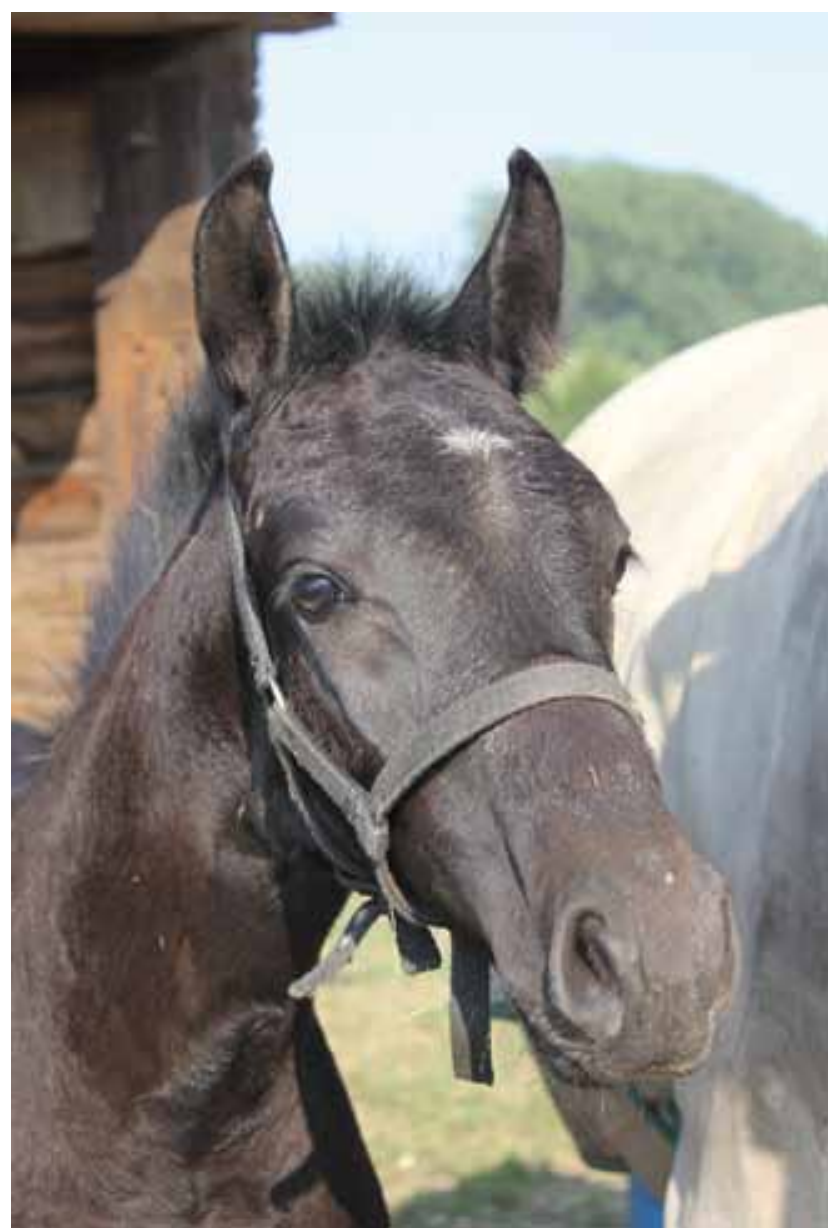

Figure 3. Macroscopic view of the foal two months after excision of the mass.

\section{ACKNOWLEDGEMENTS}

The authors wish to thank Prof. dr. Davy Vanden Broeck, Brenda Gabriels (AML, Antwerp, Belgium) and Cindy De Baere (Faculty of Veterinary Medicine of Ghent University, Merelbeke, Belgium) for performing PCR analyses.
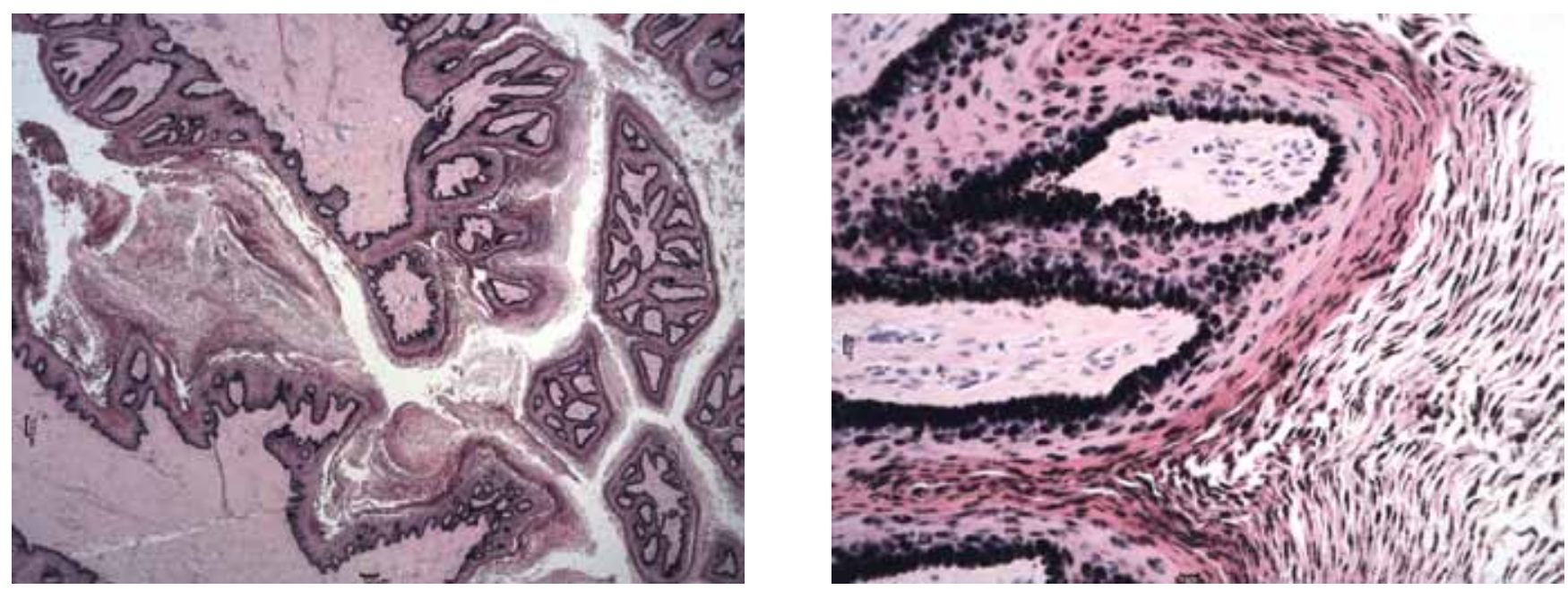

Figure 4. A. Histopathologic image illustrating the arborized stalk lined by irregular hyperplastic, pigmented parakeratotic epithelium (HE, x20). B. Detail of the epithelial lining (HE, x200). 


\section{REFERENCES}

Bogaert L., Van Poucke M., De Baere C., Dewulf J., Peelman L., Ducatelle R., Gasthuys F., Martens A. (2007). Bovine papillomavirus load and mRNA expression, cell proliferation and p53 expression in four clinical types of equine sarcoid. Journal of General Virology 88, 21552161.

Bogaert L., Martens A., Van Poucke M., Ducatelle R., De Cock H., Dewulf J., De Baere C., Peelman L., Gasthuys F. (2008). High prevalence of bovine papillomaviral DNA in the normal skin of equine sarcoid-affected and healthy horses. Veterinary Microbiology 129, 58-68.

Campen R., Zembowicz A., Liu V., Wrone D. (2003). Linear ectodermal cutaneous hamartoma. International Journal of Dermatology 42, 376-379.

Desrochers A., St-Jean G., Kennedy G.A. (1994). Congenital cutaneous papillomatosis in a one-year-old Holstein. Canadian Veterinary Journal 35, 646-647.

Dias A.P., Barcelos J.M.P., Fonseca M.E.F., da Silva Basso N.G. (1995). Congenital papillomas and papillomatoses associated with the Human Papilloma Virus (HPV) - report on 5 cases. Sao Paulo Medical Journal 113, 957963.

Garma-Aviña A., Valli V.E., Lumsden J.H. (1981). Equine congenital cutaneous papillomatosis: a report of 5 cases. Equine Veterinary Journal 13, 59-61.

Ghim S-J., Rector A., Delius H., Sundberg J.P., Bennett Jenson A., Van Ranst M. (2004). Equine papillomavirus type 1: complete nucleotide sequence and characterization of recombinant virus-like particles composed of the EcPV-1 L1 major capsid protein. Biochemical and Biophysical Research Communications 324, 1108-1115.

Junge RE, Sundberg JP, Lancaster WD. (1984). Papillomas and squamous cell carcinomas of horses. Journal of the American Veterinary Medical Association 185, 656-659.

Lange CE, Tobler K, Ackermann M, Favrot C. (2011). Identification of two novel equine papillomavirus sequences suggests three genera in one cluster. Veterinary Microbiology 149, 85-90.

Misdorp W. (2003a). Congenital and hereditary tumours in domestic animals 2. Pigs. A Review. Veterinary Quarterly 25, 17-30.

Misdorp W. (2003b). Congenital tumours and tumour-like lesions in domestic animals, 3. Horses. A Review. Veterinary Quarterly 25, 61-71.
Nishiyama S., Akiba Y., Kobayashi Y., Shiga A., Kamiie J., Shirota K. (2011). Congenital cutaneous fibropapillomatosis with no evidence of papillomavirus infection in a piglet. Journal of Veterinary Medical Science 73, $283-$ 285.

Postey R.C., Appleyard G.D., Kidney B.A. (2007). Evaluation of equine papillomas, aural plaques and sarcoids for the presence of equine papillomavirus DNA and papillomavirus antigen. The Canadian Journal of Veterinary Research 71, 28-33.

Ruppin M.P., Dennis M.M., Smith C.L., Vogelnest L.J. (2013). Extensive epidermal naevus in a foal. Australian Veterinary Journal 91, 407-410.

Scase T., Brandt S., Kainzbauer C., Sykora S., Bijmholt S., Hughes K., Sharpe S., Foote A. (2010). Equus caballus papillomavirus-2 (EcPV-2): an infectious cause for equine genital cancer. Equine Veterinary Journal 42, 738-745.

Scott D.W., Miller W.H. (2003). Neoplastic and non-neoplastic tumors. In: Equine Dermatology. W.B. Saunders, Elsevier, London, p. 700-707; p. 778-779.

Scott D.W., Miller W.H. (2011). Neoplasms, cysts, hamartomas, and keratoses. In: Equine Dermatology. Second edition, Saunders, Elsevier, London, p. 468-473; p. 510512.

Stosiek N., Ulmer R., von den Driesch P., Claussen U., Hornstein O.P., Rott. H-D. (1994). Chormosomal mosaicism in two patients with epidermal verrucous nevus. Journal of the American Academy of Dermatology 30, 622-625.

van den Top J.G., Harkema L., Lange C., Ensink J.M., van de Lest C.H., Barneveld A., van Weeren P.R., Gröne A., Martens A. (2015). Expression of p53, Ki67, EcPV2- and EcPV3 DNA, and viral genes in relation to metastasis and outcome in equine penile and preputial squamous cell carcinoma. Equine Veterinary Journal 47, 188-195.

Vitovec J., Kursa J., Kratochvil P., Skalova A. (1999). Congenital fibropapillomatosis in a piglet. Veterinary Patho$\log y 36,83-85$.

White K.S., Fuji R.N., Valentine B.A., Bildfell R.J. (2004). Equine congenital papilloma: pathological findings and results of papillomavirus immunohistochemistry in five cases. Veterinary Dermatology 15, 240-244. 